\title{
Três Faces de um Poema. Leitura do "Poema de Sete Faces", de Carlos Drummond de Andrade
}

\author{
Cristiano Perius ${ }^{1}$
}

Resumo: O presente ensaio visa a interpretar o "Poema de Sete Faces", de Carlos Drummond de Andrade. $\mathrm{O}$ exercício de redução fenomenológica, a ambiguidade, a percepçáo e o corpo próprio, entre outros conceitos da Fenomenologia da percep̧̧ão, de Merleau-Ponty, orientam o trabalho de leitura, estruturado a partir dos seguintes temas: o lado gauche, a correlação eu-mundo (que apenas se completa na poesia meridiana) e a primazia do olhar. Tal procedimento de leitura reúne o poema hepta-partido em três faces ou tensóes fundamentais, levando em conta os efeitos das imagens.

Palavras-Chave: Fenomenologia. Poesia. Maurice Merleau-Ponty. Carlos Drummond de Andrade.

Alguma Poesia, publicado em 1930, reúne os poemas escritos por Carlos Drummond de Andrade a partir da segunda metade dos anos 20. Precisamos considerar a maturidade do poeta, especialmente como livro de estréia. Contra a máxima que pondera os "pecados da juventude", reconhecemos as obras da $1^{\text {a }}$ fase sem nenhum caráter pejorativo. Antes de Alguma Poesia e ao longo de toda aquela década de grande ânimo literário, podemos constatar a formação de um grupo modernista mineiro, em diálogo com o centro. (CURY, 1988) É já Drummond em ampla atividade, exercida em diversas mãos, aliado ao meio jornalístico (Diário de Minas) e serviços burocráticos. A respeito dessa obra principiante e constantemente corrigida, examinaremos por que o "Poema de Sete Faces" é decisivo, haja vista o gauchismo e a ironia, o humour e o pessimismo crítico em curso, a partir de entáo.

A propósito do "Poema de Sete Faces", tanto quanto a coletânea Alguma Poesia, deve-se reconhecer um caldo bem cozinhado do primeiro modernismo brasileiro. No entanto, o "princípio", fictício, é apenas o nome-índice que o crítico literário encontra para a obra já estabelecida. Mas o poeta atua

\footnotetext{
${ }^{1}$ Cristiano Perius é professor de Filosofia da Universidade Estadual de Maringá (UEM) e atua nas áreas de estética e fenomenologia. E-mail: cristianoperius@hotmail.com

http://dx.doi.org/10.1590/S0101-31732017000100006
} 
livre no campo no qual o crítico procura coesão e com frequência vê mais fios, tramas e nexos do que se poderia explicar. Por isso, melhor do que a exibiçáo cronológica da obra, examinaremos suas tensôes internas. Aqui encontramos razôes para o "Poema de Sete Faces" ser fundamental e ter, mais que a anuência de ser o primeiro, outro propósito: constituir uma poética do olhar.

E ainda há outra razão, diacrônica, evocada pelo poema. Como diz Novalis, "[...] o começo efetivo é um segundo momento." A reflexão é a volta sobre si mesma, que acaba tornando efetivo - sincrônico - um elemento diacrônico, chamado por Novalis de segundo momento. O "Poema de Sete Faces" é seminal, visto anunciar algo que o crítico vê e espera explicitar. Porém, o que vê está, por ora, sub-reptício, pois, onde lê "Vai, Carlos!, ser gauche na vida", identifica a obra inteira. É retrospectivo, porque se dá na pertinência entre o "vai (Carlos) ser", e o que será. O "vai ser" de Drummond já contém, aos olhos do crítico, algo que foi. Eis o caráter performático da arte, a propriedade de ser a realização de uma imagem reflexiva. Realizaçóes pensadas, sim, mas, antes de tudo, germinaçôes, fios do tecido que vai ser. Explicaríamos melhor esse paradoxo se nos fixássemos menos no "Vai" - a que toda crítica "vem" e sempre "volta" - para tratar do "Carlos", já que um passo se sobrepóe a outro, exige um novo, só possível pelo prévio. Onde quer que vá, do ponto final ao passo inicial que abriu caminho, não foi senão marcha sua, palmo a palmo progredindo. Todavia, se o crítico tem um olhar retrospectivo, é certo que o poeta "vai", sem fixar destino. Vamos ao "Poema de Sete Faces", o qual, apesar de hepta-partido, será dividido em três temas principais.

FACE I. O gauche

$$
\begin{aligned}
& \text { Quando nasci, um anjo torto } \\
& \text { desses que vivem na sombra } \\
& \text { disse: Vai, Carlos! ser gauche na vida. }
\end{aligned}
$$

O gauche do verso 3 - Vai, Carlos! ser gauche na vida - contracena com outras metáforas: "Quando nasci, um anjo torto" (v.1); "desses que vivem na sombra" (v.2). (grifo nosso) Gauche, anjo torto e sombra são imagens que denegam. Contrariam a regra, isto que esperamos ser a via reta: o modo justo ou correto de chegar a um fim. Invertendo a norma de teor racionalista, cujas fontes remontam à filosofia moderna e à crença na luz natural da razão, Drummond expóe o lado esquerdo e náo o direito, o torto e náo o reto, a sombra e não a luz. Essa inversão é extraordinária e nos leva a duas considerações. 
A primeira delas é a ironia perante o herói clássico, que lembra, embora sem relação direta, Mário de Andrade e seu Macunaíma, "herói sem nenhum caráter". Em seguida, o itinerário estético livre dos padrôes clássicos de criação, ${ }^{2}$ uma vez que visa ao entorpecimento da razáo fora de mecanismos de controle ostensivos, evocado claramente pela última estrofe do poema:

Eu não devia te dizer

mas essa lua

mas esse conhaque

botam a gente comovido como o diabo.

Fortalecido pelas imagens noturnas de "luar", "diabo" e "embriaguez", trata-se do labor poético que contrasta a herança poética parnasiana. A poesia desce de seu reino augusto para confundir-se com o gole noturno, com o diálogo post laborem do bar. Sombra (v.2) e lua (v.26), anjo torto (v.1) e diabo (v.28) estão em sintonia com o gauche. Noite, bebida e luar aludem à atmosfera da cena intelectual do final da década de vinte, quando a boêmia se misturava à discussão de ideais estéticos de vanguarda. $\mathrm{O}$ gole de conhaque e a impossibilidade do soneto dividem um cenário de renovação de ideias, quando o sucesso da poesia não está mais na perfeição formal do objeto estético. $\mathrm{O}$ lado esquerdo, que serve de antítese à tradição cristã obstinada no exercício da moral lacerante, ironiza pelo avesso: pactua não com Deus, mas com o diabo, mencionado no último verso do poema, e mantém relação com o anjo torto, do primeiro. É o desastre do ideário clássico que se manifesta na rebeldia contra Deus e pacto com o diabo, desde os versos de Baudelaire (1985, p.422): "Oh Satan, prends pitié de ma longue misère", estribilho do poema. Lembrar de Baudelaire não é inoportuno, se há a intenção, própria à estética modernista, de propor uma poesia autêntica e liberada de qualquer tipo de cânone. Gauche é, segundo a expressão do poeta, seu "lado fatal", sua "dose diária de erro", que incorpora o defeito.

\footnotetext{
2 Para a menção das fontes teóricas dos padróes clássicos da arte, pensamos em Platão, cujo princípio de simetria, harmonia e regras áureas de composição estabelecem o conceito de imitação da natureza, a partir da beleza formal do objeto estético. Princípios "apolíneos", diria Nietzsche, contrapondo a ilusão onírica à embriaguez dionisíaca. Observe-se, nesse sentido, a seguinte frase de Nietzsche: "Apolo, como divindade, exige a medida [...]. Nada em demasia, ao passo que a auto exaltação e o desmedido eram considerados como demônios propriamente hostis à esfera nâo-apolínea, portanto, propriedades da época pré-apolínea, da era dos Titâs e do mundo extra-apolíneo, ou seja, do mundo dos bárbaros." (NIETZSCHE,1992, p. 40.) Evidencia-se aqui a contraposição entre a ordem, a medida, como princípio racional e apolíneo, e o caos, a desmesura, como princípio irracional e dionisíaco.
} 
A aceitação do imperfeito é a conjuntura implicada na crise da razão e impossibilidade artística de síntese formal ou regra áurea, de outro modo não se compreenderia o anjo torto, que circunstancia o desvio em relação à norma, bem visível, também, no poema "Deriva à esquerda", de Bento Prado Júnior (2000, p. 4):

Começa a faltar-me/ O joelho esquerdo./ Como um líquido cálido/ A dor circula, entre ossos, / Nesse minúsculo músculo motor.// Falha-me o joelho/ E, com ele, toda a esquerda perna./ Falta-me também a Faculdade de Julgar,/ Para reequilibrar o meu andar/E o próprio Mundo.// Fui condenado a derivar à esquerda,/ Para todo o sempre,/Por falta de um joelho/ (uma asa?)/ ou de uma impensável bengala lógico-metafísica.

O poema de Bento Prado Júnior é tributário ao gauchisme de Drummond. Recusar a via reta é a inclinaçấo filosófica do "anjo torto", que desiste de um princípio de regulação metafísico, o qual renuncia à síntese racional, à perfeição formal que sustentava a estética clássica. ${ }^{3}$ Dizer não à "bengala” (da) metafísica, eis o mérito do guache. Tal interpretação, embora evidente no poema de Bento Prado Júnior, é subjacente à poética de Drummond. Sem Deus, sozinho, com poucos amigos, o poeta segue seu caminho:

O homem atrás do bigode

é sério, simples e forte.

Quase não conversa.

Tem poucos, raros amigos

o homem atrás dos óculos e do bigode.

Meu Deus, por que me abandonaste

se sabias que eu não era Deus

se sabias que eu era fraco.

A bengala, na letra de Bento Prado Júnior, corrige o andar cambembe. Faz valer a dialética corretiva que a filosofia canônica trazia implícita: ordenar o passo torpe, isto é, proibir a experiência sem proveito. Andar sem bengalas,

\footnotetext{
3 Por "estética clássica" entende-se, aqui, a ideia vaga, sem mençâo explícita, das correntes artísticas que racionalizam a experiência estética. É o caso do conceito de imitação, pois mesmo Aristóteles, para quem a causa final do poema trágico é emocional e catártico, as pretensōes morais e cognitivas da arte, ainda que veladas, identificam o belo ao ideal.
} 
mancar ou derivar à esquerda, nesse sentido, são metáforas para o incerto, o hipotético, o problemático do homem. Assim, o gauche colhe as incertezas da vida. A maior virtude do gauche está em que a incerteza não é adjetivo de menos no total da vida que a literatura pesa. Irônico sinal de mais, visto que mancar é, no final das contas, andar por si mesmo, sem o socorro de apoios.

FACE 2: Eu-mundo

$$
\begin{aligned}
& \text { Mundo mundo vasto mundo, } \\
& \text { se eu me chamasse Raimundo } \\
& \text { seria uma rima, não seria uma solução. } \\
& \text { Mundo mundo vasto mundo, } \\
& \text { mais vasto é meu coração. }
\end{aligned}
$$

Rima e solução, mundo e coração, ao lado de Raimundo, formam um conjunto de palavras assonantes. Não obstante a sonoridade proporcionada pela paronomásia, o mundo é um conceito seminal. Entre o coração do poeta e a vastidão do mundo há uma sensível diferença de grandezas. ${ }^{4}$ Examinemos esse tema a partir da fenomenologia de Merleau-Ponty.

De fato, o coração maior do que o mundo perfaz as antinomias do eu estático e inflexível, observador visual - sem ser visto - o qual não participa do mundo-espetáculo, mas lhe é testemunha. No poema "Mundo Grande", da coletânea Sentimento do Mundo, dá-se a inversão desse ponto de vista. A realidade do mundo passa a ser mais importante, ao passo que o eu, insignificante. Em A Rosa do Povo, acontece o "quiasma", a "imbricação" (empiètement) e a "reversibilidade", segundo a expressão de Merleau-Ponty, entre o sentimento do eu e a facticidade do mundo, isto é, o fenômeno de produção de imagens que transgride as fronteiras lógicas entre os polos subjetivo e objetivo, através do jogo metafórico que estabelece a intencionalidade ambígua e incompleta entre os termos. Seja por espelhamento, seja por reversão, o poesia opera uma distância intencional entre o sujeito e o objeto, entre o "eu" e o "mundo", permitindo a transposiçáo de tudo isto que, nascendo em um, termine em outro, e vice-versa.

Consideremos melhor. A tensão "Eu - Mundo", iniciada no "Poema de Sete Faces”, alcança a forma definitiva e equilibrada na poesia posterior. É só a partir de Sentimento do Mundo que, com suas palavras, afirma ter "[...] resolvi-

${ }^{4}$ Afonso R. de Sant'Anna trata especialmente desse tema em seu estudo: Drummond: o gauche no tempo (1992). 
do as contradiçôes elementares de sua poesia." ${ }^{5}$ É por isso que, para a análise desse tema, que é a intencionalidade operante entre as imagens do "eu" e do "mundo", acompanharemos o "Poema de Sete Faces" à luz de alguns versos da poesia meridiana, especialmente $A$ Rosa do Povo.

Poemas como "Não se Mate" justificam o "Eu > mundo" [eu maior do que o mundo], quando a oscilação do mundo - ora escuridão, ora claridade em nada altera a rocha abismal do eu: "Você caminhal melancólico e vertical./ Você é a palmeira, você é o gritol que ninguém ouviu no teatrol e as luzes todas se apagam./ O amor no escuro, não, no claro,/é sempre triste, meu filho, Carlos, / mas não diga nada a ninguém, / ninguém sabe nem saberá." (DRUMMOND, 2002, p.58) A propósito da melancolia desse contato vertical, o eu está no centro e, ao mesmo tempo, disseminado, visto que hiper-sensível e sinestésico. Mais do que egocêntrico, introvertido, fechado, é despojado na escuta do outro que não é senão a fala de si mesmo, na fuga de si onde se vê olhando, mesmo sendo o mundo o que vê, o outro que escuta, ao transformar a horizontalidade do mundo em verticalidade do eu. Observador implacável e, por isso mesmo, por sentir as dores do mundo como suas, o poeta caminha afetado, nada esperando do mundo, apenas colhendo. Se assume as dores do mundo, não há reciprocidade, o mundo não compreende. $\mathrm{O}$ mundo é menor. $\mathrm{O}$ coração pulverizado percorre todos os cantos do mundo, desbaratado pelo eu insuperável, e se desdobra, indiviso, vendo em tudo a si mesmo, multiplicado. Esse sentimento exprime o contraste claramente apresentado no "Poema de Sete Faces", versos 24 e 25: "mundo mundo vasto mundo, / mais vasto é meu coração."

Em "Desdobramento de Adalgisa” (DRUMMOND, 2002, p.63), o poeta forja, sob o substantivo (Adalgisa), o adjetivo (adaljosa) e o verbo (adalgisar). Poder-se-ia propor uma paródia a respeito, dizendo que a substância de Adalgisa, adaljeica, mundalgisa. Essa matriz substantiva, polimorfa, alcança tudo: "A vossa Adalgisal virou duas diferentes (v. 5-6); Sou loura, trêmula, blândulal e morena esfogueteada./ Ando na rua a meu lado,/ colho bocas, olhos, dedos/ pela esquerda e pela direita (v. 8-12); quando é uma que são duas (v. 18); tem tantas direçóes/ e em nenhuma se define,/ mas em todas se resume (v. 21-23);

5 Cf.: "Meu primeiro livro, Alguma poesia (1930), traduz uma grande inexperiência do sofrimento e uma deleitação ingênua com o próprio indivíduo. Já em Brejo das almas (1934), alguma coisa se compôs, se organizou; o individualismo será mais exacerbado, mas há também uma consciência crescente da sua precariedade e uma desaprovaçáo tácita da conduta (ou falta de conduta) espiritual do autor. Penso ter resolvido as contradiçôes elementares da minha poesia num terceiro volume, Sentimento do mundo (1940)." "Autobiografia para uma revista". In: Confissão de Minas. São Paulo: Cosac e Naify, 2011, p.68. 
Saberei multiplicar-me, / e em cada praia tereis/ dois, três, quatro, sete corpos/ de Adalgisa, a lisa, frial e quente e áspera Adalgisa,/ numerosa qual Amor (v. 2428); Se fugirdes para a florestal serei cipó, lagarto, cobral eco de grota na tardel ou serei a humilde folha,/ sombra timida, silênciol entre duas pedras (v. 29-34); Se voardes, se descerdes/ mil pés abaixo do solo, / se vos matardes afim, / serei ar de respiração,/ serei tiro de pistolal veneno, corda, Adalgisa, Adalgisa eterna (v. 37-43); Eu mesma náo me limito:/ se viro o rosto me encontro,/ quatro pernas, quatro braços, / duas cinturas e um/ só desejo de amar./ Sou a quádrupla Adalgisa,/ sou a múltipla, sou a unical e analgésica Adalgisa". (v. 51-58) Primeiro dupla, depois quádrupla, Adalgisa desdobra-se em progressão aritmética, ilimitada, para náo dizer infinita, deixando onde passa e atrás de si apenas o rastro de seu olhar metanoico. O final do poema, "para onde quer que vades,/ o mundo é só Adalgisa”(v. 60-61), é o resultado final da atividade paradigmática do eu, cujo olhar é paralisante igual os olhos de Medusa.

No entanto, a Adalgisa hiperbólica, metamórfica, só podia acabar no mais puro receio do seu desdobramento aritmético. Sobrevindo a desconfiança, cisma, expondo os perigos da poesia em disposição contrária. É o período no qual a pequenez humana se faz mais patente e o mundo, um ser enorme, distante, inatingível. É nesse momento que se opera a inversão cabal da disposição do "Poema de Sete Faces", ao revelar-se o "eu < mundo" [eu menor do que o mundo]:

Não, meu coração não é maior que o mundo.

É muito menor.

Sim, meu coração é muito pequeno.

Só agora vejo que nele não cabem os homens.

Os homens estão cá fora, estão na rua.

A rua é enorme. Maior, muito maior do que eu esperava.

Mas também a rua não cabe todos os homens.

A rua é menor que o mundo.

O mundo é grande.

Tu sabes como é grande o mundo.

Viste as diferentes cores dos homens, as diferentes dores dos homens, 
sabes como é difícil sofrer tudo isso, amontoar tudo isso num só peito de homem... sem que estale.

Meu coração não sabe.

Estúpido, ridículo e frágil é meu coração.

(DRUMMOND, 2002, p.87).

"Noturno à Janela do Apartamento" esboça o estatelamento do eu frente ao mundo, nos versos acima sugeridos. Barroquismo e pequenez, entre o silêncio não contido e o inefável presumido, atingem o paroxismo:

Silencioso cubo de treva:/ um salto, e seria a morte. [...] Nenhum pensamento de infância,/ nem saudade nem vão propósito./ Somente a contemplação/ de um mundo grande e parado./ A soma da vida é nula.[...] Suicídio, riqueza, ciência.../ A alma severa se interroga/ e logo se cala. E náo sabe/ se é noite, mar ou distância. (DRUMMOND, 2002, p.88).

O verso final do poema: "Triste farol da ilha Rasa", preserva a inversão das grandezas; o eu: pequeno farol insular; o mundo: todos continentes e oceanos terrestres, onde uma ilha perece.

A circunscrição do eu (num ínfimo canto do mundo) vem associada a diferentes imagens em sintonia com o novo dispositivo: "eu $<$ Mundo". Privação do que está no mundo ausente no eu: "é a hora em que o sino toca,/ mas aqui não há sinos; é a hora em que o pássaro voa, não há pássaros.”(DRUMMOND, 2002, p. 122). Medo, pela insuficiência das forças de que dispôe: "em verdade temos medo./ Nascemos escuro./ As existências são poucas:/ Carteiro, ditador, soldado./ Nosso destino incompleto" (DRUMMOND, 2002, p. 122). Solidão e alteridade perdida frente à extensão hiperbólica do mundo: "Nesta cidade do Rio,/ de dois milhóes de habitantes,/ estou sozinho no quarto,/ estou sozinho na América" (DRUMMOND, 2002, p. 93); "Ó solidão do boi no campo,/ ó solidão do homem na rua!" (DRUMMOND, 2002, p. 94); "No cimento, nem traço/ da pena dos homens./ As famílias se fecham/ em células estanques" (DRUMMOND, 2002, p. 96). O ser privilegiado, que em parte alguma deveria ser ínfimo, desvalorizado: "O elevador sem ternura/ expele, absorve/ num ranger monótono/ substância humana" (DRUMMOND, 2002, p. 96). O riso, tão próprio do humour drummondiano, fica à garganta, uma expectativa dramática toma conta da fala, quando a graça baixa o tom: "a palavra Encanto/ recolhe-se ao livro,/ entre mil palavras/ inertes à espera” (DRUMMOND, 2002p. 96). Há uma tônica desse 
sentimento que não é, salvo por breves interrupçóes, absorvido. $\mathrm{O}$ movimento do eu permanece aquietado a uma sorte de paralisia que, em memória ao vitalismo antigo [eu > mundo], confrange-se.

A constante desolação do eu frente à impossibilidade de suportar o dinamismo do mundo, a qual se dá no confronto entre grandezas desiguais, eu pequeno, mundo grande, sofrerá uma última transformação na sequência das imagens. Apresentaremos esse novo momento, "eu = mundo" [eu igual ao mundo], a partir da fenomenologia de M. Merleau-Ponty.

$\mathrm{Na}$ Fenomenologia da Percepção, Merleau-Ponty endereça a conceitos da epistemologia moderna o rótulo de "prejuízos clássicos". O alvo da crítica se constitui, em linhas gerais, pelo pensamento reflexivo, vítima da operação intelectualista, e pelo associacionismo, vítima da operação empirista. Trata-se de duas abordagens antitéticas e incompatíveis, uma vez que tomam parti pris opostos, ou seja, o partido materialista ou objetivista, de um lado, e o partido espiritualista ou subjetivista, de outro. Ora, a solução para o problema está, segundo Merleau-Ponty, em estabelecer uma nova teoria da percepção, apta a escapar das antíteses dos modernos. Trata-se de remeter a ambas as operaçôes a mesma crítica, a saber, o ensinamento ambíguo e exemplar contido no conceito de corpo próprio, nem subjetivo, nem objetivo. Resulta disso a iniciativa de superar os prejuízos clássicos através de uma "arqueologia do sentido", segundo a expressão de Renaud Barbaras, em Do ser do fenômeno (BARBARAS, 1991), isto é, a descrição da experiência que desvela, a partir do teor da percepçáo, o sentido originário de conceitos chaves como a atençáo e o juízo, interpretados unilateralmente pelas tradiçôes subjetivistas e objetivistas.

Ora, "mundo, mundo vasto mundo, / mais vasto é meu coração", do "Poema de Sete Faces", tanto quanto "estúpido, ridículo e frágil é meu coração", do poema "Mundo Grande", são antíteses semelhantes às que Merleau-Ponty menciona. De fato, desde que entendemos o mundo por totalidade de fenômenos autônomos e independentes à consciência, o $e u$ por um princípio formal, fonte de representações, já estamos na direção de um dualismo antitético. Chamamos de subjetivo o lugar transcendental, com base no qual as representações nos aparecem; chamamos de objetivo os entes intramundanos, conteúdos representacionais da consciência. Este é o partido intelectualista, segundo o qual os objetos do mundo dependem das representaçóes da consciência. ${ }^{6} \mathrm{O}$ partido inverso - empirista - renuncia à fonte "mágica” das representaçóes,

'Esta é a prerrogativa kantiana, segundo a qual "o eu deve acompanhar todas as minhas representaçôes", isto é, ser o avalista lógico e formal de ajuizamento sobre o mundo. 
colocando no próprio mundo a chave de suas relaçóes internas. Resulta disso o "eu > mundo", poderoso e absoluto, apto a entender as leis do mundo, ou, na via inversa, o "eu < mundo", predisposto a desconfiar da faculdade de vidência, isto é, do enigmático dom da constituição. $\mathrm{O}$ encaminhamento poético a essa antítese é a percepção de que não se trata de medir forças entre o eu e o mundo, mas, ao contrário, de equilibrá-las entre si.

No poema intitulado "Caso do Vestido", de A Rosa do Povo, encontramos o seguinte verso: "O mundo é grande e pequeno." (DRUMMOND, 2002, p.163). É nesse momento que a incompatibilidade entre o polo subjetivo (o eu) e o polo objetivo (o mundo), a qual fundava uma relação de grandezas desiguais na composição das imagens, desaparece. Entretanto, isso não é tudo. Trata-se da elisão do sujeito e do objeto, segundo a "Procura da Poesia", isto é, do reconhecimento de um plano em que o eu e o mundo não contrastam, mas sofrem a ação de contaminação e de iluminação recíproca. Trata-se, segundo os conceitos da fenomenologia, do a priori de correlação, pois o sujeito e o objeto não são nada em si mesmos, mas, em funçáo de. Ora, é este a priori de correlaçáo que está operando, quando se trata da reciprocidade entre eu e mundo. Drummond permite pensar em algo como "se (eu)... então (mundo)...” e vice-versa, porque são correlatos. Trata-se de um problema genuinamente fenomenológico, pois a fenomenologia procura a constituição do mundo sem pressupor que ele já esteja dado, de um lado, assim como não o reduz à categorias transcendentais do espírito, de outro. Com o conceito de fenômeno - o que aparece - a fenomenologia toma a iniciativa de sair do idealismo sem cair no realismo, ou seja, não supóe o mundo dado - como faz o empirismo -, nem tampouco pré-formado - como faz o intelectualismo, uma vez que náo se pode pressupor que os fenômenos são revelados por uma estrutura consciente ou egológica, nem adotar o parti pris inverso, a saber, pensar que o dado possui uma estrutura autônoma e independente do sujeito. ${ }^{7}$

Não por acaso, Drummond favorece a leitura fenomenológica de poemas. Como um binômio de primeira ordem, "eu" e "mundo" são fenômenos originários para a produção poética. Nascemos no mundo, isto é, não há vazio ontológico a ser substituído pelo pleno do mundo. Por sua vez, o "eu", que tem sentidos, dirige-se ao mundo com poder incomparável de ontogênese, ser para mim, sem que possa ser outra coisa senão sentido. A característica da visão, a qual mantém o ser como ser-visto, que reduz o mundo a espetáculo

7 Para as fontes teóricas deste tema, segundo o aporte da fenomenologia, cf. o ensaio: "A dobra do corpo e a questão do dualismo" (PERIUS, 2006). 
e funda a condição de condicionante, não apaga a de condicionado, a condição de mundo em si. A confluência desse duplo faculta a possibilidade de intercâmbio e com possibilidade, a oscilação de um para outro, assim como dizemos que a visão é minha ou que o visto está em mim. Não constituímos o mundo com o pensamento lógico, e a segurança de termos uma visão confiável é menos dele que das próprias coisas. Se o sentimento de atingir as próprias coisas, de estar no mundo sem fantasmas é derivado, isto é, não vem de mim, então o mundo tem, tanto quanto eu, existência soberana, lugar assegurado na cadeia da verdade. Como aponta Merleau-Ponty (1960, p.15): “[...] nossas relaçóes com o ser comportam um duplo sentido, o primeiro segundo o qual nós somos seus, o segundo o qual ele é nosso.”

Se levamos os fios "eu - mundo" adiante, de forma a procurar a cumplicidade do grande e do pequeno, do interior e do exterior, é que a contradição encerra o exercício artístico, se é de primeira ordem. A ironia da metáfora que assina o jogo de ambivalências entre o eu e o mundo é uma tensão fundamental de sua poesia. ${ }^{8}$

FACE 3: Primazia do olhar

$$
\begin{aligned}
& \text { O homem atrás do bigode } \\
& \text { é sério, simples e forte. } \\
& \text { Quase náo conversa. } \\
& \text { Tem poucos, raros amigos } \\
& \text { o homem atrás dos óculos e do bigode. }
\end{aligned}
$$

O homem de bigode esconde, sob a marca do bigode, a particularidade de ser genérico e só nos versos seguintes - tem poucos, raros amigos (v.16), sério simples e forte (v.14), quase não conversa (v.15) - podemos completar o seu sentido. Uma face descritiva, sem dúvida, sob o signo do sigilo ("atrás de"...). Essa descrição de cinco versos, própria de um homem tímido, é a discrição de um homem reservado à presença muda do olhar. Em parte alguma é posto o "pensamento" do homem atrás dos óculos. A referência aos óculos e bigodes é corporal e sensível, enquanto o pensamento é abstrato e inteligível. A menção ao corpo, segundo Merleau-Ponty, é extraordinária, pois se opõe à tradição racionalista, tal como se lê nesta passagem de Descartes, citada na Fenomenologia da Percepção:

\footnotetext{
${ }^{8}$ Que se veja, nesse sentido, a expressão "sentimento do mundo", título da coletânea de 1940.
} 
Se por acaso olho pela janela homens que passam na rua, não deixo de dizer que vejo homens [...] mas o que vejo da janela, senão chapéus e mantos que podem cobrir espectros de simulacros que apenas se movem por mecanismos? Mas eu julgo que são homens e assim compreendo pela única potência de julgar que reside em meu espírito, isto que eu cria ver de meus olhos. (MERLEAU-PONTY, 1945, p. 41).

Há, nessa passagem, um prejuízo do corpo que Descartes autoriza. O poder de ver sem aparências, no entanto, a confirmar a certeza de não ter fantasmas, é do pensamento, não dos olhos que me trazem, além da quina da janela, o tablado do alpendre, sob o qual os homens passam. O corpo, ser sensível que se move, perfaz o movimento dos olhos, o qual Descartes acreditava subordinado. Consideraçôes como estas significam que os óculos não são de natureza descartável e que, ao invés de nos livrar da opacidade das coisas, trazem-nas com mais confiança para aqueles que os usam. O espírito, que assume o viés de pensamento e de consciência soberana, não é exterior a esse instrumento convexo e binocular que, mais que interromper a vista direta, entrega-nos a vista direita, mesmo porque não temos contato puro com a essência, ideal de conhecimento que se realize a partir da contemplação de objetos isoláveis de intercâmbio com o corpo. Dito de outro modo, o pensamento puro, sem a crosta sensível, exclui o papel vital do corpo, onde está o homem de bigodes. E, se não há contato de espírito a espírito, visão sem profundidade, sem "carne" que habite e encarne as coisas em suas lacunas e obscuridades, é porque a clareza pertence às ideias, não aos olhos. No entanto, isto que a encarnação dos olhos perde (a evidência) nada mais é senão um recobrimento metafórico da luz. Entre o pensamento (inteligível) e a visão (sensível) não há hiato. De fato, não há visão espontânea que extraia, de imediato, os significados da cultura, maneira de olhar e compreender o que é visto. Assim como aprendemos a falar, a destacar as coisas, dando nomes, vemos, no visto, seu sentido, e é possível que, em poucos anos nesse exercício de aprendizado, pouco reste de desconhecido. A matéria visível dos óculos e do bigode não é diferente dos traços do caráter, os quais falam em nome da natureza interior. Desse modo, no sinótico quadro de cinco versos há, em alegoria, uma descrição dos olhos, mas também do espírito, e, se levarmos às últimas consequências o que os versos significam, está implícito: transcendência sobre o visto que sugere, no fim das contas, um enigma do olhar imperceptível a Descartes. "Atrás dos óculos e dos bigodes" está o espírito, por certo, mas este é o significado metafísico do olhar. 
Como aponta Merleau-Ponty, em "A Dúvida de Cézanne”: "Tudo indica que os animais não sabem olhar, penetrar nas coisas sem nada esperar delas senão a verdade.” (MERLEAU-PONTY: 1988, p.120). Segundo Descartes, as informaçôes trocadas entre o espírito e os órgãos sensoriais servem para corrigir a percepção. O pensamento de ver, conforme Descartes, é uma representação bem mais segura que as intempéries da coisa vista, porque vai à essência sem permanecer no domínio corporal e sensível. A respeito dessa expectativa, há motivos de sobra para crermos que, no corpo, as pulsões têm parte, e a julgar pelo "Poema de Sete Faces", desviam-se do puro pensamento:

As casas espiam os homens

que correm atrás de mulheres.

A tarde talvez fosse azul,

não houvesse tantos desejos.

O desenho simples de uma casa não possui fisionomia de rosto humano? Cabelos são telhados, olhos são janelas, nariz e boca porta e rés do chão... No deserto e na metrópole moderna, entretanto, a casa muda, emblema da natureza habitada. Acolhe tanto o rigor do espírito errante e silencioso do homem à imensidão desértica quanto o prédio à arquitetura tensa do espaço comprimido da cidade. Fornecem abrigo e moradia, isto é, conhecem a intimidade da família. Todavia, como os homens correm, as casas calam. Ermas, distendem-se pela rua e cercam os passantes. Se as coisas pertencem à mesma dança, têm os mesmos traços e relevos, não são objetos, mas fisionomias que assediam, que respondem ao modo dos enigmas e, se respaldam como seres deste mundo, invertem os papéis do ativo e do passivo. No horizonte que as fazem casas para nós estão erguidas sobre o mesmo mundo, como a figura e o fundo. $\mathrm{O}$ outro a fundir minha carne, as coisas têm empatia e parentesco, altruísmos que as valorizam tanto quanto um ser anímico. Se levarmos a sério o verso de Drummond, veremos que a relação que estabelece com as coisas não é a do ponto de vista do sujeito, nem, ao contrário, delas a nós, do objeto, mas o vaivém e o balanço que faz o paradoxo de olhar e de ser visto. Contra a tradição clássica que racionaliza a sensibilidade artística, ${ }^{9}$ o "Poema de Sete

\footnotetext{
9 A crítica ao racionalismo é uma característica do gauche. Vejamo-la claramente, no poema "Áporo": "em verde, sozinha,/ antieuclidiana,/ uma orquídea forma-se." (DRUMMOND, 2002, p. 142.) A inversão desse ideal "apolíneo", cujo princípio persegue o formalismo geométrico, também é visível no poema "A Flor e a Náusea": "Uma flor nasceu na rua!/ É feia. Mas é uma flor." (DRUMMOND, 2002, p. 119.)
} 
Faces" consagra o olhar:
O bonde passa cheio de pernas:
pernas brancas pretas amarelas.
Para que tanta perna, meu Deus, pergunta meu coração.
Porém meus olhos
não perguntam nada.

Entre o coração, que pergunta, e o olhar, não há apenas uma diferença de grau, mas, de natureza. Segundo Husserl (apud ESCOUBAS, 1991, p. 13): "A intuição de uma obra de arte se completa ao seio de uma estrita colocação entre parênteses de toda disposiçáo existencial do intelecto, assim como de toda disposição do sentimento e da vontade." A disposição estética implica uma mudança de atitude em relação ao mundo natural. Nela [dimensão estética], os objetos são postos entre parênteses, isto é, "reduzidos" a um modo de aparecer que suspende todo e qualquer tipo de interesse, seja especulativo ou utilitário sobre as coisas. Em outras palavras, a fenomenologia aproxima a experiência estética da experiência originária e sensível, onde o mundo aparece em sua fenomenalidade pura, sem conceito. Se Husserl aproxima a intuição fenomenológica da intuição estética, como ele mesmo diz [sic]: "[...] ver fenomenológico é primo-irmão do ver estético", é porque "[...] o artista se comporta como fenomenólogo e não como cientista ou psicólogo, que operam por observação, na intenção de se informarem sobre a natureza e sobre o homem." (ESCOUBAS: 1991, p.13).

Essa visão pura, "desinteressada", corresponde à "neutralidade" da arte, isto é, à ausência, em primeira instância, de valor moral e cognitivo para o produto estético. Fenomenologia e arte estão unidas na mesma visada, que é olhar o mundo pela primeira vez. Mais ainda, esse olhar puro, sem conceito, vê o mundo sem equivalentes subjetivos e objetivos. Que se leia, nesse sentido, o comentário de Patrícia Limido-Heulot (2010, p. 5):

Os atos do sentimento e da vontade: a alegria (pelo que é), a tristeza (pelo que náo é), o desejo (pelo que poderia ser), etc., são as tomadas de um partido existencial dos sentimentos. Tal é a atitude natural ordinária. Trata-se de uma posição oposta a da intuição estética, onde a existência disto que aparece náo é posta como real, mas, entre parênteses. 
Em outras palavras, a redução fenomenológica aparece espontaneamente na arte, pois destitui o olhar da obrigaçáo de ver o mundo segundo uma visão utilitária ou interessada. E isso é assim, porque

[...] a atitude estética, que aboliu todo interesse natural, psicológico, ou mesmo teórico, é entáo inteiramente conduzida para o prazer da aparição: é um prazer que deixa a existência fora de jogo para se consagrar à apariçáo, aos seus modos, ao seu como, logo, uma atitude que se instala na contemplaçáo sensível para si e apenas para si [pour lui-même et pour lui seul]. (LIMIDO-HEULOT, 2010, p. 7).

O olhar do artista, assim, opera a redução fenomenológica, porque mobiliza o sensível como tal ao aparecer, sem predicação linguística, como forma de limite (e de paradoxo).

Se o "Poema de Sete Faces" conduz o silêncio do olhar ao estado máximo, é porque o sensível contém em si mesmo o estatuto de objeto fenomênico, antes do conceito. A presença pura das coisas, anterior à linguagem, confirma a prerrogativa de que a predicação linguística corrompe a estrutura do dado. Como afirma Maurice Blanchot (apud COLLIN, 1971, p. 196): "A linguagem, como escritura, não é posição, mas, proposição.”. Por essa razão, a redução fenomenológica assume, aos olhos de Merleau-Ponty, na Fenomenologia da Percepção, a admiração diante do mundo, isto é, o espanto de ver o mundo sem conceito:

A melhor fórmula da redução é sem dúvida aquela que lhe dava Eugen Fink, o assistente de Husserl, quando falava de uma "admiraçáo" diante do mundo. A reflexáo náo se retira do mundo em direção à unidade da consciência enquanto fundamento do mundo; ela toma distância para ver brotar os fios intencionais que nos ligam ao mundo para fazê-los aparecer, ela só é consciência do mundo porque o revela como estranho e paradoxal. (MERLEAU-PONTY, 1945, p.viii).

Se o "Poema de Sete Faces" edifica um abismo entre a língua, que pergunta, e olhos, "que náo perguntam nada" (v.13), é porque o sensível possui a qualidade de ser originário em face à linguagem articulada. ${ }^{10} \mathrm{Ver}$, sem perguntar, porque as perguntas nunca acabam, ao passo que o silêncio recua ao solo

\footnotetext{
${ }^{10}$ Lembremo-nos de que a fala, segundo a tradição da filosofia, é traduzida por lógos, razão discursiva, e, por isso mesmo, articulada, no sentido de fônica, falada.
} 
perceptivo da presença muda do olhar. Não ter palavras significa perder o conceito das coisas, como a fala articulada é o conjunto de signos que constituem a atualidade da língua. De fato, a fala conceitua, ao passo que a visão nunca é interrompida. A fala reúne, enquanto a visão dispersa. $\mathrm{O}$ coração pergunta, mas os olhos não respondem. Apenas olham.

PERIUS, Cristiano. Three faces of a poem: a reading of the Poema de Sete Faces by Carlos Drummond de Andrade. Tans/formlação, Marília, v. 40, n. 1, p. 109-126, Jan./Mar., 2017.

\begin{abstract}
The purpose of this essay is to interpret Carlos Drummond de Andrade's Poema de Sete Faces (Poem of Seven Faces). Phenomenological reduction, ambiguity, and corporeality, among other concepts in the Phenomenology of Perception by Merleau-Ponty, lead and structure a reading based on the following themes: the left side, the correlation between self and world, and the primacy of perception. Such a reading brings together the seven part poem and dwivides it into three aspects or fundamental tensions, taking into consideration the effects of metaphor.
\end{abstract}

KeYwords: Phenomenology. Poetry. Maurice Merleau-Ponty. Carlos Drummond de Andrade.

\title{
REFERÊNCIAS
}

ANDRADE, C. D. Poesia completa. Rio de Janeiro: Nova Aguilar, 2002.

. Autobiografia para uma revista. In: . Confissão de Minas. Sáo Paulo: Cosac e Naify, 2011. p. 67-69.

BARBARAS, R. De l'être du phénomène: sur l'ontologie de Merleau-Ponty. Grenoble: Jérôme Millon, 1991. . Le tournant de l'expérience. Paris: Vrin, 1998.

BAUDELAIRE, C. As flores do mal. Edição bilíngüe. Rio de Janeiro: Nova Fronteira, 1985. COLLIN, F. Maurice Blanchot et la question de l'écriture. Paris: Gallimard, 1971.

CURY, M. Z. F. Horizontes modernistas: o jovem Drummond e seu grupo em papel jornal. Belo Horizonte: Autêntica, 1998.

DESCARTES, R. Méditations métaphysiques: objetions et réponses, suivi de quatre lettres. Traduction de Jean-Marie e Michelle Beyssade. Paris: Flammarion, 1992.

DUCHARME, R. L'avallé des avalés. Paris: Gallimard, 1966.

ESCOUBAS, E. Art et phénoménologie. Revue La Part de L'CEil, Bruxelles: Académie Royale des Beaux-Arts de Bruxelles, n. 7, 1991.

KANT, I. Crítica da faculdade do juizo. Traduçáo de Valério Rohden e Antonio Marques. 2. ed. Rio de Janeiro: Forense Universitária, 1995. 
LIMIDO-HEULOT, P. L'expérience esthétique, entre feinte intentionnelle et épreuve réelle. Bulletin d'analyse phénoménologique, v. 7, p. 5, 2010. Disponível em : <http: // popups.ulg.ac.be/bap.htm> . Acesso em: 22 jan. 2017.

MERLEAU-PONTY, Maurice. Phénoménologie de la perception. Paris: Gallimard, 1945. . Éloge de la philosophie et autres essais. Paris: Gallimard, 1960. p. 15. Sens et non-sens. Paris: Nagel, 1966. . A dúvida de Cézanne. In: Textos escolhidos. São Paulo: Abril Cultural, 1988. p.113-126.

NIETZSCHE, F. O nascimento da tragédia. Tradução de J. Guinsburg. São Paulo: Companhia das Letras, 1992.

NUNES, B. Crivo de papel. 2. ed. São Paulo: Ática, 1998.

PERIUS, C. A dobra do corpo e a questão do dualismo. In: GONÇALVES, A. et al (Org.). Questóes de filosofia contemporânea. São Paulo: Discurso Editorial, 2006. p. 107-117.

PRADO JÚNIOR, B. Poema inédito. Folha de S. Paulo, 17 mar. 2000. Caderno Mais.

RICOEUR, P. A metáfora viva. Tradução de Dion Davi Macedo. São Paulo: Loyola, 2000.

SANT'ANNA, A. R. Carlos Drummond de Andrade: análise da obra. 3. ed. Rio de Janeiro: Nova Fronteira, 1980. . Drummond: o gauche no tempo. 4. ed. Rio de Janeiro: Record, 1992.

Recebido em 27/07/2016

Aceito em 18/11/2016 
PERIUS, C. 